操船シミュレータによる海難の事故分析に関する研究

一第拾雄洋丸とパシフィック・アレス衝突事件についてー

小林 弘明*・濱田 俊秀**・片岡 高志***

\title{
A Study on the Causes of Marine Casualty Utilizing Ship Maneuvering Simulator \\ - In the Case of the Marine Casualty of YUYO MARU \\ No.10 and PACIFIC ARES-
}

Hiroaki KOBAYASHI, Toshihide HAMADA and Takashi KATAOKA

\begin{abstract}
A lot of studies have been carried out to analyze the causes of marine casualties. But it is not enough studies from view point of the research that investigate the relation between the physical factor and marine casualty.

Ship maneuvering simulators are very effective for clarifying the factors and analyzing the causes of the marine casualties.

In this paper, firstly it was examined how physical factors influence the causes of the marine casualties using the ship maneuvering simulator in Tokyo University of Mercantile Marine.

The marine casualty of YUYO MARU No.10 and PACIFIC ARES in Nov. 1974 was studied.

Finally we got the basic characteristics that are often causes of the marine casualty, as follows.

(1) Ship's operator going through the fairway passage are liable to delaying start to avoiding actions.

(2) Avoiding actions which is operated in fairway passing maneuver are mainly speed control instead of course changing which is more effective to avoid collision.
\end{abstract}

\section{1.はじめに}

海難の事故原因の究明は数多く実施されているが、海難事故と物理的な関係因子との関係を研究した事 例は非常に少なく、関係因子と事故との関係の究明も不十分である。

最近の操船シミュレータの視界再現と操縱性能の再現に関する性能及び技術面での向上を踏まえ、操船 シミュレータを用いた海難の事故分析の研究を実施した。海難事故の関係因子としては、環境特性、船舶 特性、操船内容があるが、操船シミュレータによる操船ではこれら関係因子を変化させることが可能であ り、事故分析に大変有効である。

研究の第 1 歩として、東京商船大学の操船シミュレータを使用し、昭和49年11月に発生した第拾雄洋丸

* 正会員 東京商船大学（干135-8533 東京都江東区越中島2-1-6)

** 正会員 ナビックスライン（株）（テ100-8151 東京都千代田区一ツ橋1-1-1）

***正会員 鳥羽商船高等専門学校（テ517-8501 三重県鳥羽市池上町1-1） 
とパシフィック・アレス衝突事件に関し、事故分析を試みた。

\section{2. 研究目的と解析方法}

\section{1 研究目的}

海難事故の関係因子である環境特性 (交通環境、自然環境等)、船舶特性 (操縦性能、船種、船型等) 及び 操船内容 (操作内容、操作タイミング等)について、これら関係因子が事故発生に与える影響度を調查する ことが研究の目的である。

\section{2 研究方針}

海難事故の従来の解析方法では、事故の直接原因である人的要因 (ヒューマンエラー)に重点を置いて議 論している。今回は、人的要因の背景にあって、ヒューマンエラーを誘起している事故の間接原因である 環境特性、船舶特性及び操船内容について調查することとする。

海難事故の物理的な関係因子との関係を十分に究明するためには、操船シミュレータの持つ再現性、反 復性の特徴が必須条件である。最近の操船シミュレータの性能及び技術の発展は、この条件に十分耐えら れると考えられることから、操船シミコレータを活用した操船実験により調査を実施した。

2.3 第拾雄洋丸とパシフィック・アレス衝突事件に対する解析方法

本海難事故は、雄洋丸が巨大船でLPGタンカーという危険物積載の特殊船舶であったこと、また海上交 通安全法第 3 条及び旧海上衝突予防法第19条の定型的航法規定が適用されない特殊な航法関係にあったこ と、さらには当該事故が、東京湾内で発生し社会的に大きな反響を呼んだこと、そして海難審判資料が他 の事件に比較してかなり充実していたことから、本海難事故を今回実験のケーススタディとして選択した。

本海難事故に関する研究では、環境特性としては視程、航路設定、船舶特性としては操縱性能を考慮し 解析を実施した。操船内容としては、操作内容及び操作タイミングについて、複数の船長による操船実験 を実施することにより、一般的な操船内容を抽出し、次に操作内容及び操作タイミングと事故との関係に 重点を置いて解析を実施した。

\section{3. 海難事故の再現}

第拾雄洋丸とパシフィック・アレス衝突事件の再現は、以下のような項目を反映した。

3.1 供試船の再現

今回の実験には、雄洋丸及びパシフィック・アレスを再現して使用することとし、以下のような資料を 参考に船舶の操縱特性を推定した。

(1) 雄洋丸の再現

(1) 雄洋丸の要目表

(2) 雄洋丸の操縱性能に関する資料

1）試運転成績書

口）推定速力計算書

八）雄洋丸を建造した造船所による満載時の速力推定データ

(2) パシフィック・アレスの再現

(1) パシフィック・アレスの要目表

(2) パシフィック・アレスの操縦性能に関する資料

イ）試運転成績書

3.2 衝突海域の再現

今回の実験では、事故当時の視程が 2 マイルであったことから衝突海域付近の地形の再現は必要なく、 以下の項目についてのみ再現した。

(1) 事故時のブイ配置

衝突海域を含む海図及び海上保安庁水路部への事故当時のブイ位置の確認により、主に中ノ瀬航路及び 木更津航路を示す事故時のブイ配置を再現した。 


\section{(2) 事故当時の視程}

海難審判庁裁決録 (以下裁決録とする) によると 事故当時の視程は 2 マイルとなっているので、今 回実験の視程の設定は 2 マイルとした。

\section{3 衝突過程の再現}

裁決録を基本に本衝突事件に関する研究資料等 も併せて、衝突の過程を推定し再現した。図1に 衝突に至るまでの状況を示す。

(1) 第拾雄洋丸の再現

第拾雄洋丸の速力は、主要な中ノ瀬航路ブイの 通過時間により、衝突の 4 分前までは港内全速前 進13ノットとし衝突時の速力を9.4ノットとした。

雄洋丸の針路は、中ノ瀨航路の航路法線と同じ 基準針路21度とした。

また、裁決録によると、雄洋丸は航路の中央か

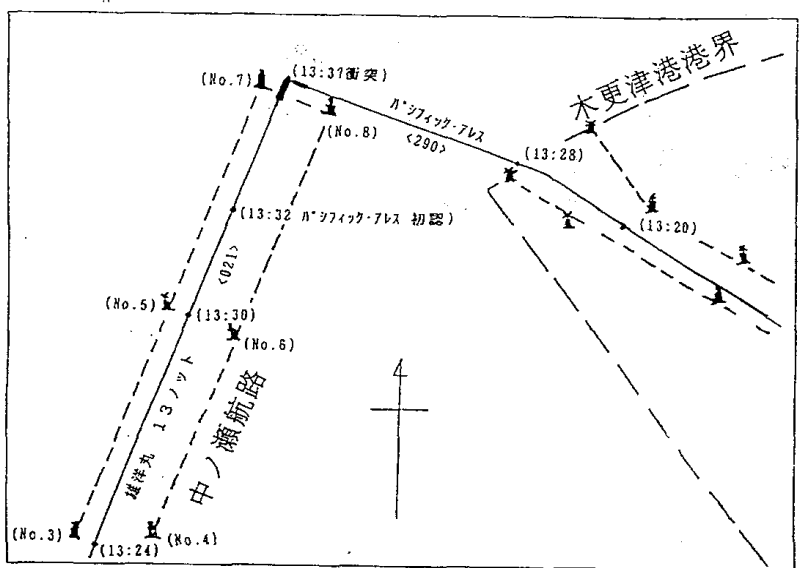

図 1 衝突に至るまでの状況概略図

ら $150 \mathrm{~m}$ 程度左側を航行しており、今回実験の初期位置も航路の中央から $150 \mathrm{~m}$ 左側に設定した位置から寒 験を開始することにした。

(2) パシフィック・アレスの再現

パシフィック・アレスの速力は、木更津航路ブイの通過時間及び雄洋丸からの方位により、衝突の 4 分 前までの速力を9.2ノットとし衝突 4 分前から衝突時までの速力を8.0ノットとした。

パシフィック・アレスの針路は、290度で航進させることとした。

\section{4. 操船シミュレータによる実験}

今回の実験では、特に雄洋丸の避航動作内容に着目して議論することから、避航動作内容に関する用語 を以下のように定義する。

(1) 避航操作の種類：機関操作、舵操作及び機関・舵操作のこと。

(2) 操作内容: 各避航操作の具体的な操作内容のこと。例えば機関操作であれば $\mathrm{FA}$ (全速後進)、HH(半 速前進)、SE (機関停止)、舵操作であればS10度 (右舵10度)、S35度 (右舵一杯) 等を指す。

(3) 操作タイミング : 各操作を実施した時の衝突予想地点までの距離 $(\mathrm{m})$ で示す。

(4) DCPA：本船と他船の 2 船間の最接近距離 $(\mathrm{m})$ 。但し、数値計算データについては、船体重心間の 距離 $(\mathrm{m})$ で示す。

\section{1 解析の方針}

裁決録によると、「衝突の主たる原因は、中ノ瀬航路北口に著しく接近する針路のまま雄洋丸の前路に進 出したパシフィック・アレスの不当運航であるが、また雄洋丸の船長に対しても他船の来航に気づくのが 遅れたばかりでなく、臨機避譲の処置が緩慢であった」との指摘がある。本海難事故の事故分析を実施する 上で、この雄洋丸船長の臨機避譲の処置が緩慢であったとの指摘に着目し、ここでの臨機避譲の処置と事 故との関係について、環境特性、船舶特性及び操船内容を変化させることで事故分析を実施した。

\section{2 実験害施時の注意事項}

実験は、以下のような項目を遵守しながら実施した。

(1) 本船は航路航行義務船(航路設定のない場合を除く)とする。

(2) 右から横切りの他船がある。

(3) レーダは使用できない。

(4) 実験毎に付加される操船内容に関する条件の中で操船する。

4.3 実験害施前のブリーフィング

実験の供試船に対する習熟訓練前に、以下の資料を使って操縦性能を把握するためのブリーフィングを 実施した。 
(1) 操縱性能に関するデータ

(2) 主要目表

4.4 供試船に対する実験実施前の習熟訓練

実験前に、本船となる雄洋丸及びコンテナ船のそれぞれの船舶を自由に操船し、操縦性能を害感するた めの習熟訓練を実施した。

4.5 実験終了時のヒアリング調查

操船実験の内容を補完するために、簡単なヒアリング調査を各実験終了時に実施した。

\section{5. 操船実験と解析}

5.1 雄洋丸とパシフィック・アレス衝突事故時の避航動作内容の検証

裁決録によると、事故時の雄洋丸船長の実施した避航措置は機関操作のみであり、その操作内容及び操 作タイミングは表 1 に示すとおりである。

今回の操船シミュレータ実験においても、事故に至らせた原因を明確にするために、この避航動作内容 を検証する必要がある。

害験は、本船を雄洋丸、他船をパシフィック・ アレスとし、航路設定有り、視程 2 マイルのシナ リオを使用して実施した。避航操作の種類は事故 時と同様に機関操作のみとし、避航動作の開始時 期を事故時に雄洋丸の船長が避航動作を開始した 時点 (衝突予想地点までの距離 $1,389 \mathrm{~m}$ ) とした。以 下この時点をA. T(Action Timing) と呼ぶ。操船 実験は、4名の船長により実施した。

図 2 に操船者全員の機関操作の内容及び操作夕 イミングを時系列で示す。衝突予想地点までの距 離(操作タイミング)を横軸にとり、縦軸に機関操 作内容を時系列で示したものである。避航開始時 期A. T分ら直ちに機関を停止 (SE) し、その後全速 力後進 (FA)を実施している操船者もいるが、操船 者全員が衝突を回避できていない。つまり、雄洋 丸の船長が避航動作を開始した時点A. Tでは、ど のような機関操作を実施しても衝突を回避できな いことがわかった。

以上のことから、事故の発生は避航動作の操作 内容及び操作タイミングに密接に関係しているこ とが明らかとなった。そして、この避航動作内容 之操船結果は、航路航行義務と雄洋丸の操縱性能 に大きく影響されることが、実験の設定条件から 推察することができる。

従って、以下の項目について詳細な分析を実施 した。

(1) 避航操作のタイミングと事故との関係

(2) 避航操作の種類と事故との関係

(3) 航路航行義務と事故との関係

(4) 操縦性能と事故との関係

5.2 避航操作のタイミングと事故との関係 避航開始時期A．Tからの操作タイミングでは、

表 1 雄洋丸の事故時の避航動作内容

\begin{tabular}{|c|l|}
\hline 経過時間 & 機関操作内容 \\
\hline 衝突4.0分前まで & FULL AHEAD; 13ノット \\
4.0 分前 & STOP ENGINE \\
3.5 分前 & HALF AHEAD \\
3.0 分前 & DEAD SLOW AHEAD \\
2.5 分前 & STOP ENGINE \\
1.0 分前 & FULL ASTERN \\
衝突時 & 速力 9 ノット強 \\
\hline
\end{tabular}



図 2 避航開始時期A.Tからの操作内容と操作タイミ ング 
機関操作のみの避航動作による衝突回避はできな いことがわかった。避航開始時期 A. T以前の操作 タイミングで避航動作を実施し、避航操作タイミ ングと事故との関係を調査した。

実験は、事故発生に対する操作タイミングの影 響を調查するために、避航動作を開始するのを他 船を視認した時点(衝突予想地点までの距離約 $2,700 \mathrm{~m})$ からとし、それ以後操船者は自由に避航 動作を実施できることとした。以下この時点をR. $\mathrm{T}$ (Recognition Timing) と呼ぶ。機関操作のみに より、4名の船長による操船実験を実施した。

図 3 に機関操作の操作内容と操作タイミングを 時系列で示す。操作はR.Tから開始可能であるが、 操船者により操作開始時期は異なり、また全操船 者が段階的な機関操作を実施していることがわか る。

段階的な機関操作による避航動作は、他船を視 認後一定の観湘時間を経てから行われ、避航動作 の操作タイミングに、航路外航行船の行動を期待 するため生じる行動遅れが発生することは明らか である。このような段階的な機関操作を実施する ことは、航路航行における避航時の機関操作とし ては一般的な操作形態であることが確認された。

よって、この段階的な機関操作を数値計算デー 夕を基に分析し、段階的な機関操作が操船結果に どのよらな効果を及ぼすのか分析することとする。

図 4 は、衝突予想地点までの距離(操作タイミン グ)を横軸にとり、縦軸に雄洋丸が横軸で示す操作 タイミングで各機関操作を実施したときの、二船 の船体重心間の最接近距離をDCPAで表したもの である。

図中のDCPA250mの線は、限界值を示し衝突を 回避するための最小のDCPAの值である。480mの 線は、離隔距離 $1 \mathrm{~L}$ (雄洋丸の船長 $(227 \mathrm{~m}$ ) を $1 \mathrm{~L}$ と する)を確保するためのDCPAの值である。

まず、図4によると、全速後進(FA)を使用する 場合、操作タイミングが衝突予想地点の $2,000 \mathrm{~m}$ 手 前で全速後進を実施すると、約 $560 \mathrm{~m}$ のDCPAが確 保でき、操作タイミングが $1,000 \mathrm{~m}$ まで遅れると、 130mまでDCPAが小さくなることがわかる。また、

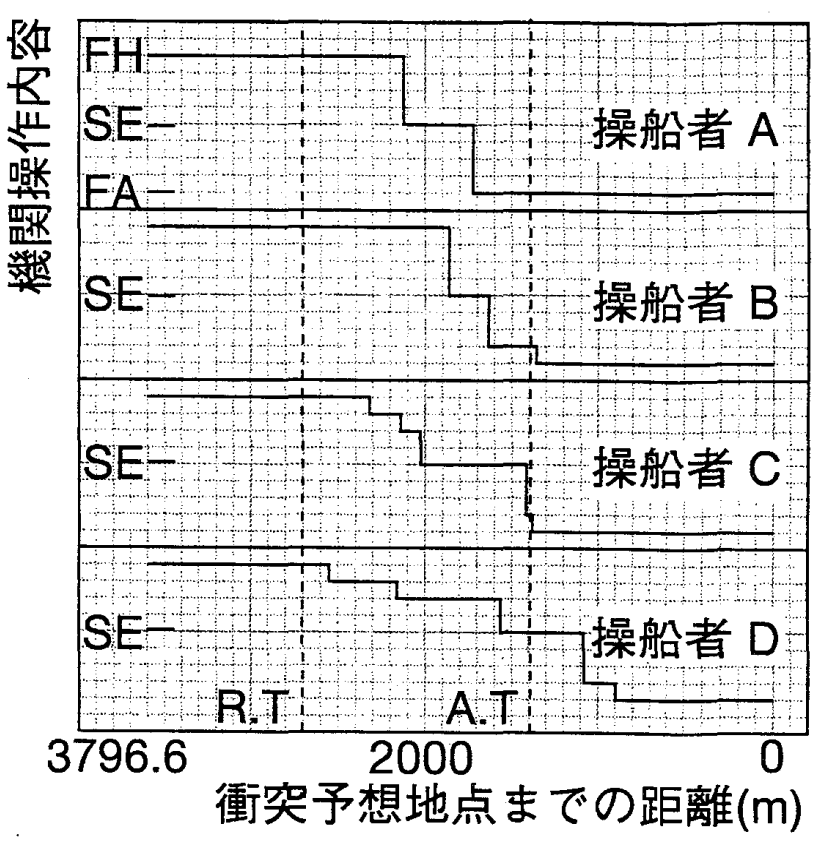

図 3 避航開始時期R.Tからの操作内容と操作タイミ ング

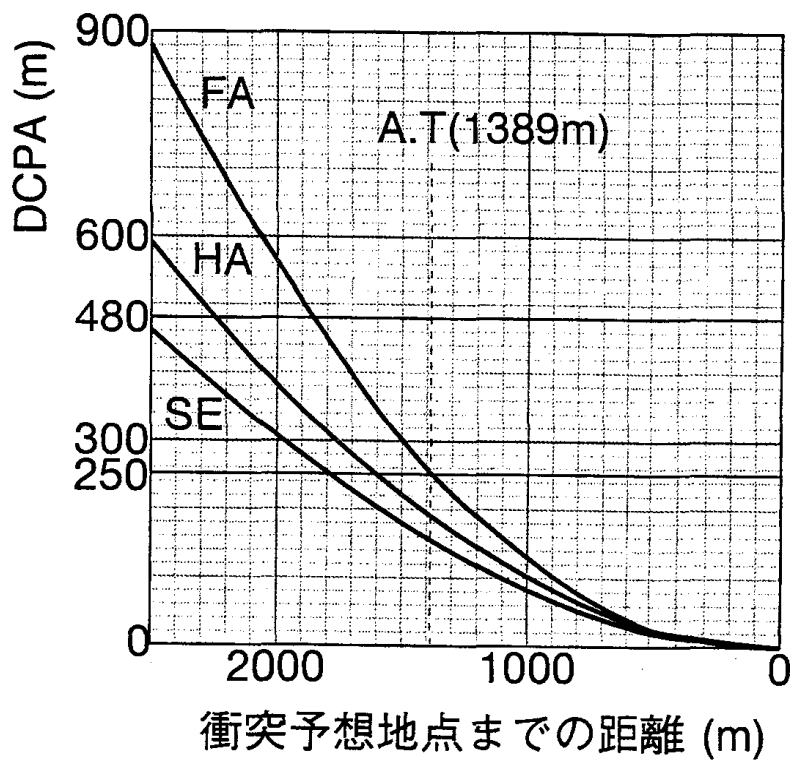

図 4 機関操作による操作タイミングとDCPAとの 関係 操作タイミングが避航開始時期A.Tでは、全速後進で $250 \mathrm{~m}$ 、半速後進 (HA) で $190 \mathrm{~m}$ 、機関停止 (SE) のDCPAとなることが判る。

図 5 (a) 及び (b) の操船者A、Bの例は、段階的な機関操作による操船結果を示している。

操船者Aの場合（図 5 (a)) は、初期動作の機関停止のタイミング、全速後進を実施するタイミングのどち らも比較的早いので、離隔距離 1 L以上のDCPAを確保した例である。

操船者Bの場合（図 5 (b)) 放、全速後進を実施する操作タイミングは、避航開始時期A．Tより遅く、決し て早い操作タイミングではないが、それ以前の半速後進及び機関停止の操作タイミングが適切で、衝突を 


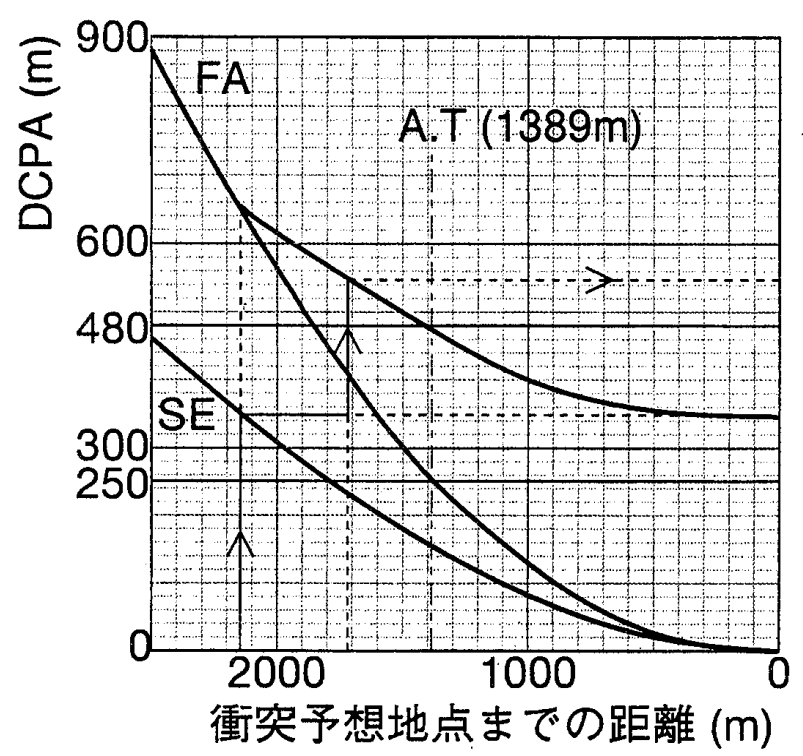

（a）操船者Aの場合

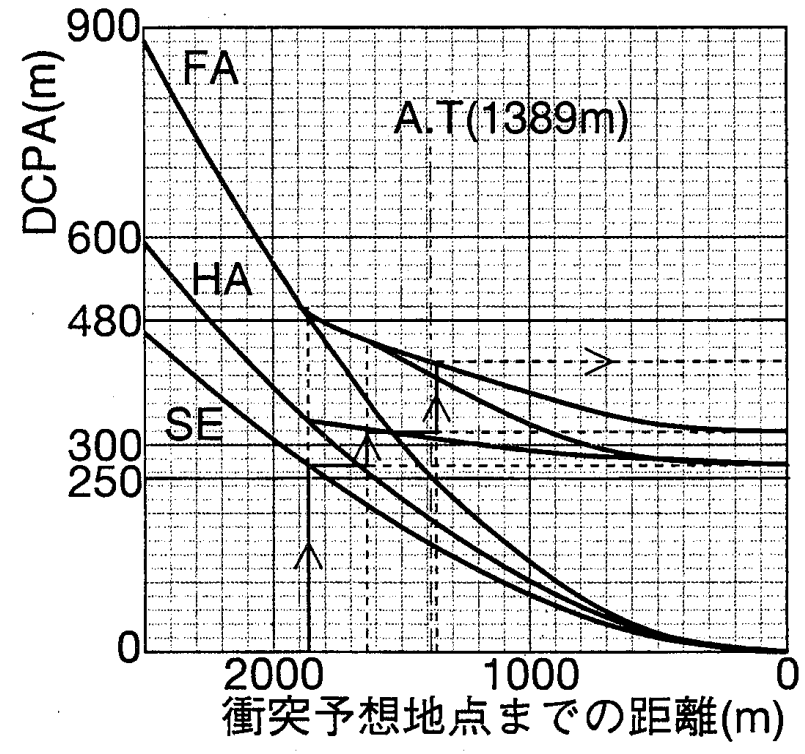

（b）操船者Bの場合

図 5 段階的な機関操作による操船結果

回避した例である。

以上のことから、機関操作内容及び操作タイミ ングの組み合わせは、自船の操縦性能と航路航行 義務等の避航動作に対する制約条件により決定さ れ、DCPAの確保に非常に重要であることが明ら かとなった。

5.3 避航操作の種類と事故との関係

事故時の避航操作の種類は、機関操作のみであ るが、一般にこの事故の状況での避航操作の種類 としては、機関操作のみ、舵操作のみ、機関・舵
表 2 ＼cjkstart避航開始時期A.Tからの操船によるDCPA

\begin{tabular}{|c|l|l|l|}
\hline 操船者 & \multicolumn{3}{|c|}{$\mathrm{D}$ C $\mathrm{P}$} \\
\cline { 2 - 4 } & 機関操作のみ & 舵操作のみ & 機関・舵操作 \\
\hline $\mathrm{A}$ & 0.0 (衝突) & 340.9 & 356.0 \\
$\mathrm{~B}$ & 0.0 & 174.3 & 154.5 \\
$\mathrm{C}$ & 0.0 & 172.2 & 188.5 \\
$\mathrm{D}$ & 0.0 & 164.0 & 129.0 \\
\hline
\end{tabular}

操作の 3 とおりが考えられる。機関操作以外の避航操作を実施し、避航操作の種類と事故との関係を調查 した。

実験は、避航操作の種類の違いによる影響を調查するため、避航操作の種類を舵操作のみ及び機関・舵 操作とし、避航開始時期をA，Tからに限定して 4 名の船長による操船実験を実施した。

それぞれの避航操作について、4 名の船長の操船結果を示したのが表 2 である。

機関操作による避航操船では、操船者全員が衝突を回避できないことは、先に述べたとおりであるが、 舵操作及び機関・舵操作による避航操船では、操船者全員が衝突を回避できた。

図 6 (a)に、舵操作の限界であるS35度 (右舵一杯) で避航し、航路航行を維持するように操船した場合の、 操作タイミングとDCPAとの関係を数值計算データにより求めた結果を示す。衝突予想地点までの距離を 横軸にとり、縦軸に他船との船体重心間の最接近距離をDCPAとして表している。図 $6(\mathrm{a})$ を求めるための 数值計算の方法を図 6 (b)に示す。最も速やかに最大のDCPAを確保するために、S35度で避航し、航路航 行を維持するためにP 35 度の戻し舵を取り、原針路と同じ針路で航路の右側端に沿って航行させる。この避 航動作の開始の操作タイミングを变化させ、他船とのDCPAの関係を求めたのが図 6 (a)である。例えば、 操作タイミングが衝突予想地点までの距離 $2,000 \mathrm{~m}$ の場合、DCPAは $430 \mathrm{~m}$ となり、操作タイミングが $1,000 \mathrm{~m}$ では、DCPAは $180 \mathrm{~m}$ と小さくなることが判る。

約 $800 \mathrm{~m}$ が衝突を回避するための操作タイミングの限界值(DCPA100mで他船と接触しない時の值)で、 雄洋丸の $1 \mathrm{~L}$ 以上の離隔距離 (DCPA320m で離隔距離 $1 \mathrm{~L}$ 確保できる)を確保しようとすると、1,400m以 上前から避航することが必要となる。 


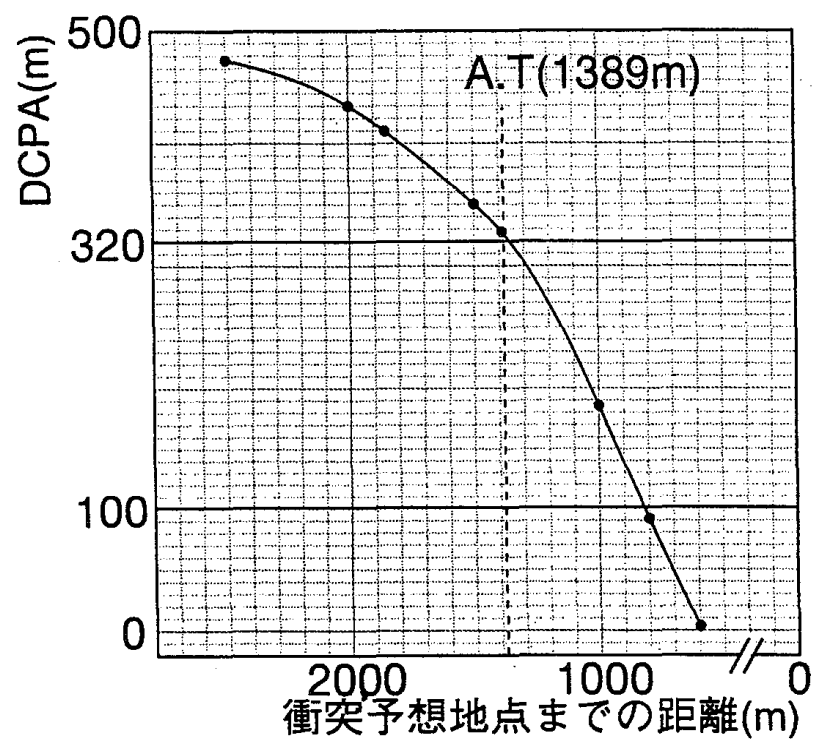

(a) 舵操作による操作タイミングとDCPAと の関係

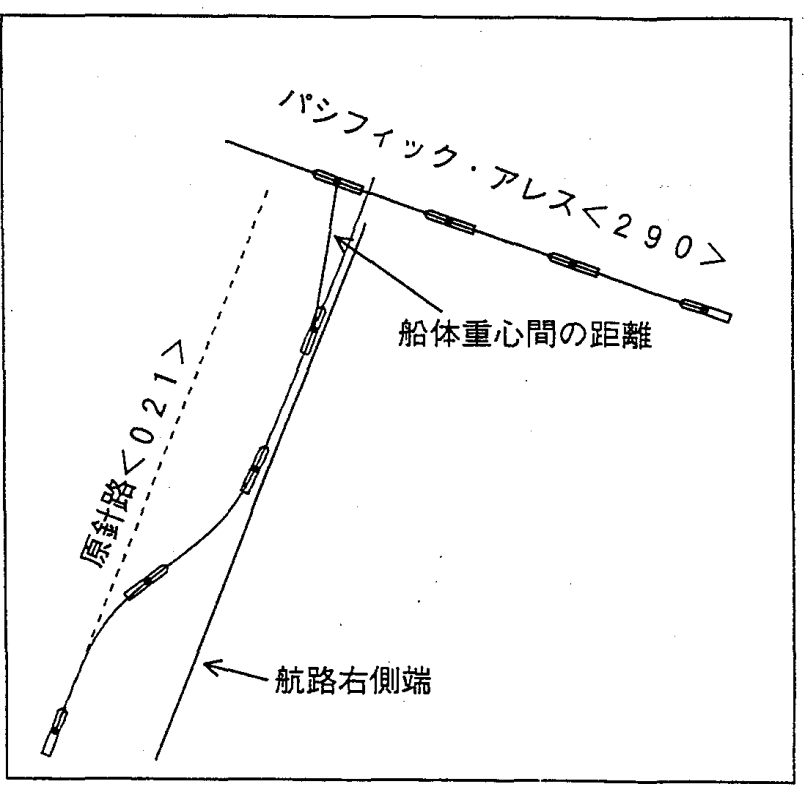

（b）舵操作による避航動作の数值計算法

図 6 舵操作による避航動作

また、航路内での舵操作による避航では航路幅で制約されるが、最大で雄洋丸の1.7Lまでは離隔距離を 確保できることがわかる。

機関操作の限界である全速後進の場合と、舵操作の限界であるS35度 (右舵一杯) の場合を比較した結果を 表 3 に示す。

衝突を回避するための限界値(接触しないための 值)と、雄洋丸の $1 \mathrm{~L}$ 離隔距離を確保するのに、。 約 $500 \mathrm{~m}$ から $600 \mathrm{~m}$ 、機関操作より舵操作の方に余 裕があることがわかる。

以上のことから、舵操作による避航動作は、機 表 3 操作タイミングとDCPAの関係

\begin{tabular}{|l|l|l|}
\hline 避航動作 & 限界值 & 離隔距離 1 L \\
\hline 機関操作 & $1,400 \mathrm{~m}$ & $1,900 \mathrm{~m}$ \\
\hline 舵操作 & $800 \mathrm{~m}$ & $1,400 \mathrm{~m}$ \\
\hline
\end{tabular}
関操作に比較して有効な避航動作であることが判 った。本事故例は、航路航行義務により避航水域 に制約はあるが、変針動作により十分避航可能であり、本海難事故のような切迫した状況では、特に舵操 作による避航が有効である。

\section{4 航路航行義務と事故との関係}

裁決録によると「雄洋丸の船長は、相手船の避航を期待しながら、その動静を見守っていて、自船が避譲 の処置をとる時機を失した。との記述がある。ここでの相手船の避航を期待させたものが、自船の航路航 行義務であることが推察できる。よって、航路航行義務という環境特性が、避航操作の種類及び操作タイ ミングに与える影響を調查した。

実験は、航路航行義務の影響を調查するために、航路ブイを配置し航路設定をしたシナリオとブイを配 置せず航路設定をしないシナリオで視程は 2 マイルとし、本船を雄洋丸、他船をパシフィック・アレスと して実施した。避航操作の種類は、機関・舵操作とし、避航開始時期をR. Tとして 4 名の船長により操船 実験を実施した。

航路航行義務のある場合の避航操作の種類をみてみると、2 名の操船者については、舵操作のみでなく 機関操作も併用している。航路航行義務のない場合は、操船者全員が舵操作のみで避航しており、航路航 行義務による影響が、機関操作を利用する避航動作を導いていることが判る。

積極的に避航動作を実施した操作タイミングについて、航路航行義務がある場合と義務がない場合とで 比較したのが図 7 である。全操船者について航路航行義務のある場合の方が、避航のための操作が遅れて 
いることがわかる。よって、航路航行義務が、操 作タイミングの遅れを導いていることが判る。

以上のことから、航路航行義務は、舵操作が使 用可能であるにも拘らず、機関操作を使用させる ような傾向を操船者に与えるとともに、操作タイ ミングの遅れも導くことがわかった。

5.5 操縦性能と事故との関係

以上の議論から、操作タイミングの重要性が指 摘された。運動は操作タイミングと操縦性能によ って変化する。そこで停止性能の優れているコン テナ船と雄洋丸の性能の違いが、避航動作の操作 タイミングに与える影響を調查した。

実験は、操縦性能の違いによる影響を調查する ために、本船に停止性能の異なる雄洋丸とコンテ ナ船を設定し、他船をパシフィック・アレス、航 路設定有り、視程 2 マイルのシナリオで害施した。 コンテナ船の再現は、(1)昭和58年建造のコンテナ

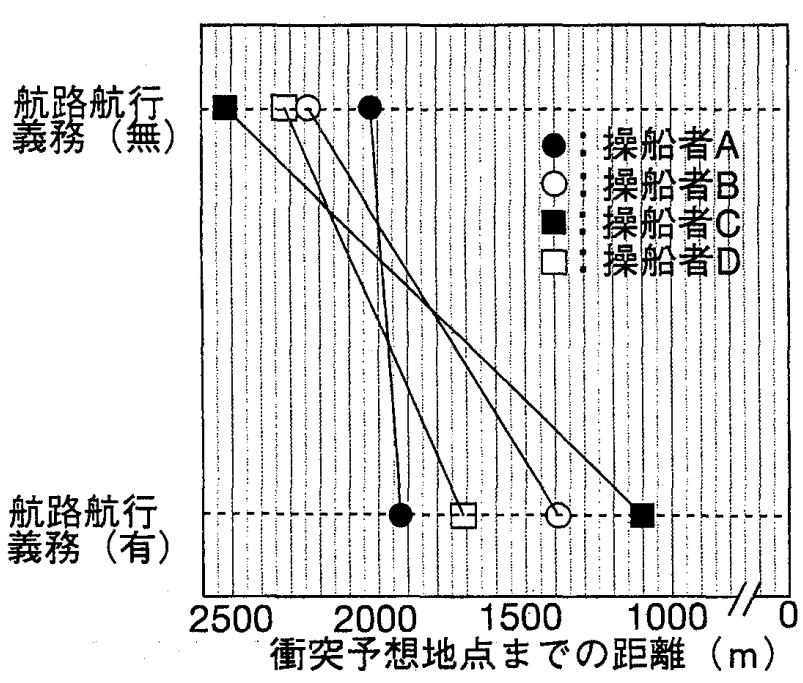

図 7 航路航行義務が操作タイミングに与える影響

船の要目表、(2)コンテナ船の操縦性能に関する資料を参考に操縦特性を推定した。

避航操作の種類は機関操作のみとし、避航開始時期をR. Tとして 4 名の船長により操船実験を実施した。

停止性能とDCPAならびに操作タイミングの関係を示しているのが図 8 である。操作タイミング(衝突予 想地点までの距離)を横軸に、DCPAを縦軸にとり、各操船者每に雄洋丸とコンテナ船で比較している。図 8によると、コンテナ船の方が雄洋丸より操作タイミングが遅れているにも拘らず、DCPAはより大きく 確保できていることがわかる。

図 9 は、雄洋丸とコンテナ船の減速特性から、機関操作のみの場合のDCPAを求めたものである。雄洋 丸とコンテナ船のデータを比較すると、カーブの立ち上がりの違い、つまり停止性能の違いが明膫である。 雄洋丸は避航開始時期A. Tからは機関操作のみでは避航できないが、コンテナ船であれば、A. Tからで も十分避航でき、全速後進以外の半速後進あるいは微速後進でも避航できることがわかる。

以上のことから、雄洋丸とコンテナ船の停止性能の差は、限界值(衝突回避のための操作タイミング)で

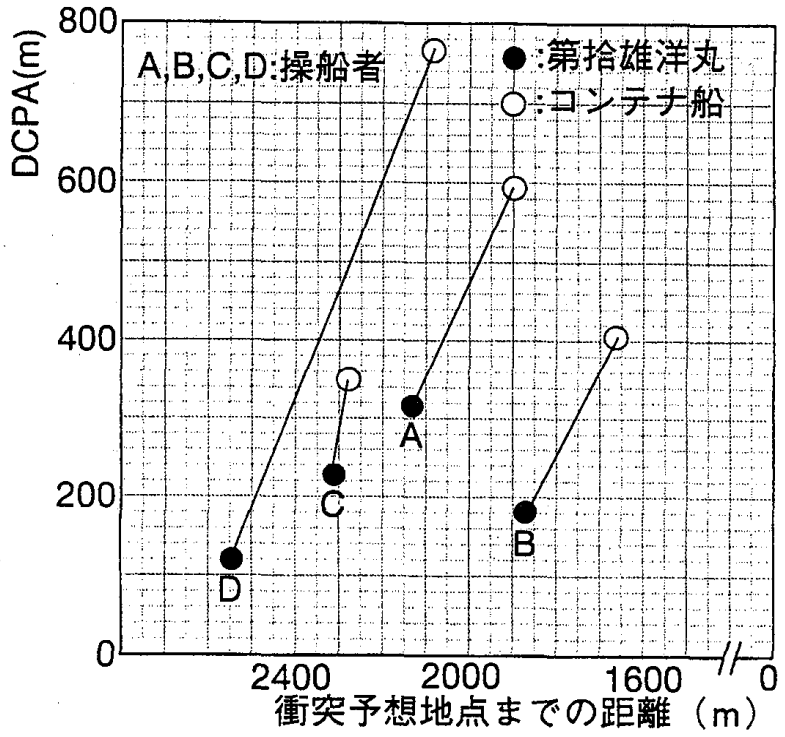

図 8 停止性能とDCPAならびに操作タイミング の関係

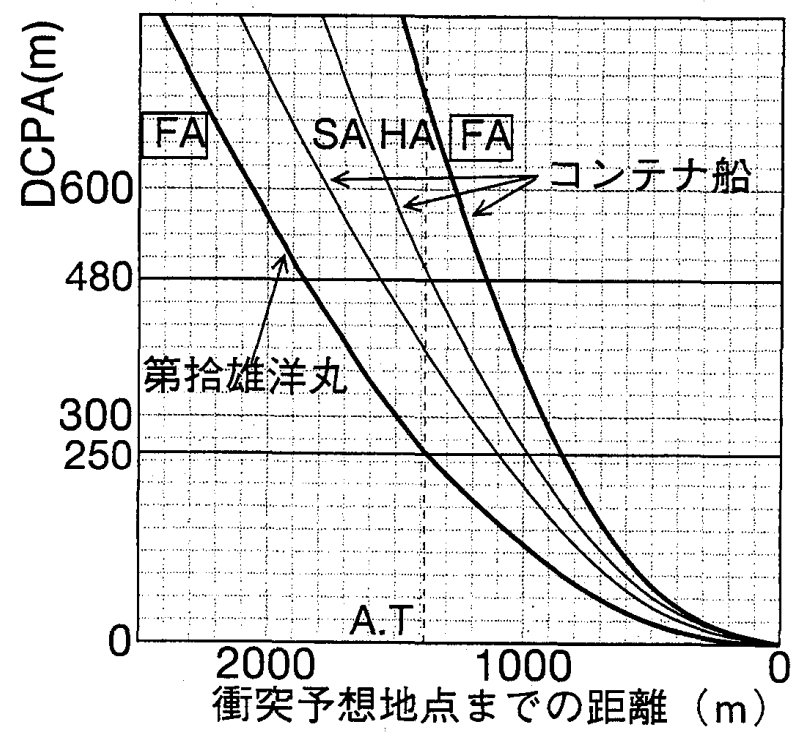

図 9 操作性能の異なる二船のDCPAの比較 
見ると、約 $500 \mathrm{~m}$ (雄洋丸の約 $2 \mathrm{~L}$ ) コンテナ船に余裕があり、事故の発生に雄洋丸の停止性能が大きく影響 していることがわかった。

\section{6. まとめ}

本研究を実施した結果、以下のようなことが明らかとなった。

（1）航路航行義務の影響は、避航動作の操作タイミングを遅らせ、切迫した状況を発生させる。更に、 避航動作としては、より有効である舵操作よりも機関操作を操船者に導く傾向がある。

(2) 操作タイミングは、切迫した状況では非常に重要であり、特に操縦性能の劣る船舶については、わ ずかな操作タイミングの遅れが事故発生へつながる。 以上のことから、次のことが言える。

(1) 本海難事故の直接原因は、ヒューマンエラーであるが、そのヒューマンエラーを誘起した背景とし て、環境特性である航路航行義務と雄洋丸の操縱性能が、間接原因として大きく影響している。

よって、航路設定する場合、航路航行船の操船者の特性を考慮し、周辺環境への十分な配慮が必要 である。また、操船者側は、航路航行が避航操船へ及ぼす影響として、機関操作を使用する傾向と操 作タイミングの遅れが生じることを認識し、本船の操縱性能を十分に考慮しながら効果的な避航手段 を選択する必要がある。

(2) 海難防止のためには、海難事故の間接原因である関係因子への対策が重要である。関係因子の抽出 及び事故と関係因子との関係の解明には、操船シミュレータによる調查、検討が非常に有効である。

\section{7. おわりに}

今後の課題として、以下のことが重要である。

7.1 海難事故防止のために

今回選択した海難事故例は、航路航行に関係する特殊な航行環境での事故であった。今後多くの海難事 故例について、このような操船シミュレータによるケーススタディーを実施し、データを積み重ねること により、海難事故の予防対策として有益な指針を与えると考えられる。

7.2 操船シミュレータを海難防止に活用するために

事故原因の分析と事故の未然防止のための研究手段として、操船シミュレータをより有効に活用するた めには、次の各項の充実が望まれる。

(1) 供試船を再現するための、操縱性能に関する詳細な資料。

（2）衝突海域を再現するための、地形、航行環境及び自然環境に関する詳細な資料。

(3) 衝突過程を再現するための、レーダ映像データ等の詳細な資料。

\section{参 考 文 献}

(1) 海難審判庁裁決録と証拠資料.

(2) 國司彰男：第拾雄洋丸・パシフィック号衝突事故とその処理, 海上保安と海難 第10節.

(3)（社）日本造船研究協会：「SR175研究部会 加減速時における操船性能に関する研究」報告書 昭和55年 3 月.

\section{質 疑 応 答}

斎藤和夫(鳥羽商船高等専門学校)：海難要因と人間の過誤についてどのよらにお考えか。

濱田俊秀: 本文でも述べたと㧍り、海難の直接原因は人的要因、つまりは人間の過誤であると処理される ことが多くあります。しかし、人的要因を誘起した背景として間接原因としての環境特性あるいは船舶 特性があります。海難防止のためには、人的要因にのみ限定せず、間接原因も非常に重要な要因である ことから、間接原因の究明は、事故防止対策のため大変重要であると考えます。 